\title{
Influence of Chemical Composition of Selected Materials on the Roughness of Cutting Edge and the Width of HAZ
}

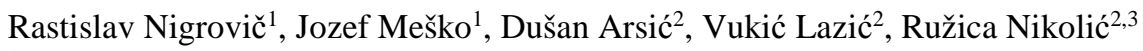 \\ ${ }^{1}$ University of Zilina, Univerzitná 1, Department of Technological Engineering; rastislav.nigrovic@ fstroj.uniza.sk, jo- \\ zef.mesko@fstroj.uniza.sk \\ ${ }^{2}$ Faculty of Engineering, University of Kragujevac, Sestre Janijić 6, Str., 34000 Kragujevac, Serbia, e-mails: \\ vlazic@kg.ac.rs; dusan.arsic@ fink.rs \\ ${ }^{3}$ Research centre, University of Žilina, Univerzitná 8215/1, 01026 Žilina, Slovakia; ruzicarnikolic@ yahoo.com
}

The presented article deals with the technology and principals of laser cutting. The article describes the properties of $\mathrm{CO}_{2}$ laser beam, input parameters of laser cutting process, assist gases, the interaction of the cut material and the stability of laser cutting. The chemical compositions of cut materials and their influence on the cutting properties focusing on the roughness of the surface, are described as well. In the experimental part the roughness of the surface was measured by using the 3D scanning and evaluation of the microstructure in the HAZ area was provided.

Keywords: Laser cutting, HAZ width, Roughness,

\section{Acknowledgement}

Research presented in this paper was partially financially supported through realization of project VEGA no. 1/0186/09-(V-13-013-00) - responsible investigator: Jozef Meško and by the Ministry of Education, Science and Technological Development of Republic of Serbia through Grants TR35024 and ON174004 and Slovak state budget by the project "Research Centre of the University of Žilina" - ITMS 26220220183.

\section{References}

[1] SILVFAST, W. T. (2004). Laser Fundamentals, Cambridge University Press, 666p. ISBN 0-521-83345-0.

[2] CARISTAN, L. C. (2004). Laser cutting guide for manufacturing. Dearborn, Michigan, USA: Society of Manufacturing Engineers, 452p. ISBN 0-87263-686-0.

[3] KONAR, R., PATEK, M., ZRAK, A.(2015) Ultrasonic testing of non-ferrous materials in the foundry industry. In: Manufacturing Technology: journal for science, research and production, Vol. 15, No. 4, s. 557-562. ISSN 1213-2489.

[4] ZRAK, A., KONAR, R., JANKEJECH, P. (2015). Influence of chemical composition in steel on laser cutting stability. In: Manufacturing Technology: journal for science, research and production, Vol. 15, No. 4, s. 748-752. ISSN 1213-2489.

[5] KONAR, R., MICIAN, M., HLAVATY, I. (2014). Defect detection in pipelines during operation using Magnetic Flux Leakage and Phased Array ultrasonic method. In: Manufacturing technology, Vol. 14, No. 3, pp. 337-341. J.E. Purkyne University, Ústi nad Labem. ISSN 1213-2489.

[6] KONAR, R., MICIAN, M. (2014). Non-destructive testing of welds in gas pipelines repairs with Phased Array ultrasonic technique. In: Manufacturing technology, Vol. 14, No. 1, pp. 42-47. J.E. Purkyne University, Ústi nad Labem. ISSN 1213-2489.

[7] MESKO, J., ZRAK, A., MULCZYK, K., TOFIL, S. (2014). Microstructure analysis of welded joints after laser welding. In: Manufacturing technology, Vol. 14. No. 3, pp. 355-359. 341. J.E. Purkyne University, Ústi nad Labem. ISSN 1213-2489.

[8] PATEK, M., KONAR, R., SLADEK, A., RADEK, N. (2014). Non-destructive testing of split sleeve welds by the ultrasonic TOFD method. In: Manufacturing technology, Vol. 14, No. 3, pp. 355-359. J.E. Purkyne University, Ústi nad Labem. ISSN 1213-2489.

[9] LAGO, J., GUAGLIANO, M., NOVY, F., BOKUVKA, O., (2016). Influence of laser shock peening surface treatment on fatigue endurance of welded joints from S355 structural steel. In: Manufacturing technology: journal for science, research and production. Vol. 16, No. 1, pp. 154-159. ISSN 1213-2489.

[10] ZAPOMĚL, J., DEKÝŠ, V., FERFECKI, P., SAPIETOVÁ, A., SÁGA, M., ŽMINDÁK, M. (2015). Identification of Material Damping of a Carbon Composite Bar and Study of Its Effect on Attenuation of Its Transient Lateral 
Vibrations. In: International Journal of Applied Mechanics, Vol. 7, No. 6, (2015)1550081 (18 pages). DOI: 10.1142/S1758825115500817.

[11] DANIELEWSKI, H., BANAK, R., DOMAGALA, A. (2013). The Experimental Analysis of Striation Pattern Created During Laser Cutting. In: Transcom 2013, Žilina, Slovakia.

[12] SKOCOVSKY, P., BOKUVKA, O., KONECNA, R., TILLOVA, E. (2006). Náuka o materiáli pre odbory strojnícke, EDIS vydavatel'stvo ŽU, 349s. ISBN 80-8070-593-3

[13] SEJC, P., BELIAK, R., SVEC, P., ROSKO, M. (2006). Computer simulation of heat affected zone during MIG brazing of zinc - coated steel sheets. In: Kovové materiály. Metallic materials. Roč. 44, č. 4. s. 225-234, ISSN 0023-432x

\section{Paper number: M2016199}

Copyright () 2016. Published by Manufacturing Technology. All rights reserved. 